\title{
Konsep Ekonomi Pada Masa Rasulullah
}

Ideologi tentang ekonomi Islam lahirseiring dengan diturunkannya ayat Al Qur'an dan masa kehidupan Rasulullah Nabi Muhammad saw. pada ujung abad 6 masehi hingga permulaan abad 7 masehipraktik sistem ekonomi Islam sendiri telah ada dan telah dilaksanakan oleh Rasulullah SAW selaku seorang Rasul teladan untuk umat muslim. Bangsa Arab sendiri sudah termasyur sebagai pedagang sebelum masuk periode Rasulullah Saw.

Perekonomian pada masa Rasulullah ini memiliki karakter umum yaitu komitmennya yang menjujung tinggi pada etika dan norma, dan kepeduliannya yang besar terhadap keadilan dan etis dalam roda syariah, dan sumber daya ekonomi tidak boleh ditumpuk oleh segelintir orang dan harus beredar agar seluruh umat memeperoleh kesejahteraan. Pasar sendiri memiliki peranan penting dalam melaksanakan sistemekonomi, pemerintah dan juga masyarakat harus berperan aktif dalam untuk mewujudkan negara yang sejahtera dan menegakkan keadilan ${ }^{1}$.

Salah satu kebijakan yang dikeluarkan oleh rasulullah SAW pada saat itu adalah Pemasukan utama untuk negeri di masa Rasulallah Saw. Merupakan zakat serta ushr. Keduanya bukan pajak dan tidak diperlakukan semacam pajak, zakat serta ushr ialah kewajiban agama serta tercantum salah satu pilar Islam, pinjama- pinjaman, duit tebusan para tawanan, khumus fadhla, serta wakaf, nawaib, rikaz, zakat fitrah, wujud lain sadaqah.

Masuk tahun tahun ke 2 setelah hijrah shadaqah fitrah diwajibkan. Shadaqah dikenal juga sebagai zakat fitrah, ini diharuskan pada setiap bulan puasa Ramadhan. Besarannya yaitu: sebebanyak satu sha (gelas) kurma, gandum (berley), tepung keju atau kismis, atau setengah Sha gandum untuk tiap muslim, budak atau orang bebas, laki-laki atau perempuan, muda atau tua dan dibayar sebelum shalat Id fitri. Zakat diwajibkan pada tahun ke-9 H. sementara shadaqah fitrah pada tahun ke-2 H. pakar hadits melihat zakat telah diwajibkan sebelum masuk tahun ke-9 H. ketika Maulana Abdul Hasan berkata zakat diwajibkan setelah hijrah dan dalam kurun waktu lima tahun setelahnya. Sebelum diwajibkan zakat bersifat sukarela dan belum ada peraturan khusus atau ketentuan hukum. Peraturan mengenai pengeluaran zakat di atas muncul pada tahun ke-9 H. Tatkala pondasi Islam telah kuat, lingkungan negara melebar dengan cepat sehingga orang-orang beramai-ramai memeluk agama Islam.

\footnotetext{
${ }^{1}$ Ibnudin Fauzan, Pemikiran Ekonomi Pada Masa Nabi Muhammad, Risala, Vol.5, No.1 , Hal.52
} 
Manajemen yang dibuat yaitu, cara pengumpulan zakat, barang yang kena zakat, batas-batas zakat dan tingkat persentase zakat untuk barang yang berbeda-beda ${ }^{2}$.

Menurut Saifullah zakat menurut bahasa (luqhat) berasal dari kata zakat merupakan bentuk masdar yang berarti berkah, tumbuh, bersih, suci dan baik. Dikatakan suci karena karena zakat dapat harta pemilik harta dari sifat tamak (rakus), syirik, kikir dan bakhil. Zakat dikatakan tumbuh, karena zakat akan melipatgandakan pahala bagi muzakki serta membantu kesulitan ekonomi dan keuangan bagi para mustahik . Dan zakat dikatakan berkah karena zakat memberikan keberkahan pada harta seseorang yang telah berzakat. Zakat secara etimologi bermakna suci, berkembang, berkah, dan juga berarti tumbuh dan berkembang. Sedangkan menurut terminologi, zakat adalah memberikan sebagian harta kepada yang berhak menerima, dengan syarat tertentu ${ }^{3}$.

\section{DAFTAR PUSTAKA}

Fauzan, I. (2019). THE THE THINGKING OF ISLAMIC ECONOMY IN MUHAMMAD PROPHET ERA (PEMIKIRAN EKONOMI ISLAM PADA MASA NABI MUHAMMAD). Risâlah, Jurnal Pendidikan dan Studi Islam, 5(1, March), 51-61

Putra, T. W. (2019). PENGHIMPUNAN DANA ZAKAT INFAK DAN SEDEKAH DI BADAN AMIL ZAKAT NASIONAL. Laa Maisyir: Jurnal Ekonomi Islam, 6(2), 246-260.

Winarno, W. (2017). SEJARAH PEMIKIRAN EKONOMI ISLAM DI MASA RASULALLAH SAW. ASY SYAR'IYYAH: JURNAL ILMU SYARI'AH DAN PERBANKAN ISLAM, 2(1), 27-46.

${ }^{2}$ Winarno, Sejarah Pemikiran Ekonomi Islam Di Masa Rasulullah SAW, Asy Asyar'iyyah, Vol. 6, No. 2, Hal. 29-33

3 Trisno Wardy Putra, Penghimpunan Dana Zakat Infak Dan Sedekah Di Badan Amil Zakat, Laa Maisyir, Vol. 6, No. 2, 2019, Hal. 284 